Acknowledgments: We extend special appreciation to the APBRN member physicians who participated in this study: Gary Bullock, DO; Leigh Copeland, MD; English Gonzalez, MD; Robert Kynerd, MD; Vicki Moore, MD; Marion "Barney" Sims, MD; and Terry True, MD; and Beverly VonDer Pool, MD.

\section{References}

1. Fiore M, Bailey W, Bennett G, et al. Treating Tobacco Use and Dependence: Clinical Practice Guideline. Rockville, Md: US Department of Health and Human Services, Public Health Services; 2000.

2. US Department of Health and Human Services. The Practical Guide: Identification, Evaluation, and Treatment of Overweight and Obesity in Adults. Bethesda, Md: Public Health Service, NHLBI Obesity Education Initiative, North American Association for the Study of Obesity; October 2000. NIH publication 00-4084.
3. US Department of Health and Human Services. Clinical Guidelines on the Identification, Evaluation, and Treatment of Overweight and Obesity in Adults: The Evidence Report. Bethesda, Md: Public Health Service, National Heart, Lung, and Blood Institute; September 1998. NIH publication 98-4083.

4. Wagner EH. Chronic disease management: what will it take to improve care for chronic illness? Eff Clin Pract. 1998;1:2-4.

5. Wagner EH, Austin BT, Davis C, Hindmarsh M, Schaefer J, Bonomi A. Improving chronic illness care: translating evidence into action. Health Aff (Millwood). 2001;20:64-78.

6. Glasgow RE, Orleans CT, Wagner EH. Does the Chronic Care Model serve also as a template for improving prevention? Milbank $Q$. 2001;79:579-612, iv-v.

\title{
Bringing the Behavioral Health Improvement Program (BeHIP) to Rural Kentucky
}

\author{
Paul Dassow, MD, MSPH; ${ }^{1}$ David Hoke, MS ${ }_{i}{ }^{2}$ Kimberly Ann Moore, $\mathrm{RD}_{i}{ }^{3}$ M. Ann Williamson, RN \\ ${ }^{1}$ Department of Family and Community Medicine, University of Kentucky, Lexington, Ky \\ ${ }^{2}$ Health and Wellness Program, University of Kentucky, Lexington, Ky \\ ${ }^{3}$ University of Kentucky, Lexington, Ky \\ ${ }^{4}$ Kentucky Ambulatory Network, University of Kentucky, Lexington, Ky \\ Ann Fam Med 2005;3(Suppl 2):S43-S45. DOI: 10.1370/afm.356
}

Conflicts of interest: none reported

CORRESPONDING AUTHOR

Paul Dassow, MD, MSPH, K307, Kentucky Clinic, Lexington, KY 40536, pdass1@email.uky.edu

\section{PURPOSE}

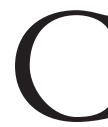

ost-effective strategies for assisting patients in behavior change are needed at the primary care level. The purpose of this project was to determine the feasibility and effectiveness of linking rural practices with an established telephonic counseling service housed at an academic medical center.

\section{METHODS}

We enrolled 32 rural primary care clinicians (14 practices) from the Kentucky Ambulatory Network and educated them about the counseling services available to their patients through the Behavioral Health Improvement Program (BeHIP) at the University of Kentucky, Lexington, Ky. Clinicians referred their patients for smoking cessation or exercise counseling by giving them a prescription that was printed with the program contact information. Once patients called, their consent was obtained, and they were matched with a personal health counselor who performed behavioral assessment and staging, assisted patients with goal setting, and scheduled telephonic follow-up. All protocols were approved by the University of Kentucky's Institutional Review Board. An overview of the counseling program for sedentary lifestyle is presented in Table 1.

\section{LESSONS LEARNED}

One lesson learned was that rural primary care clinicians were eager for external resources that can assist their patients in behavior change, and were willing to refer their patients to such programs. Of the 34 clinicians initially contacted, only 2 declined to participate. Clinicians received no remuneration for their time spent orienting to the program (about 1 hour) or for their time spent talking to their patients about the program or making referrals.

Of the 32 clinicians who consented to participate, 25 actively referred patients during the 8 -month study 


\begin{tabular}{|c|c|c|c|c|}
\hline \multirow[b]{2}{*}{ Characteristic } & \multicolumn{4}{|c|}{ Patient's Stage of Readiness to Change } \\
\hline & Precontemplation & Contemplation & Preparation/Action & Maintenance \\
\hline $\begin{array}{l}\text { Initial call } \\
\text { content }\end{array}$ & $\begin{array}{l}\text { Greeting, information regard- } \\
\text { ing program, informed } \\
\text { consent regarding study } \\
\text { participation, initial staging, } \\
\text { goal setting, scheduling of } \\
\text { follow-up call }\end{array}$ & & & \\
\hline $\begin{array}{l}\text { Subsequent call } \\
\text { content }\end{array}$ & NA & $\begin{array}{l}\text { Greeting, query regarding } \\
\text { readiness for preparation, } \\
\text { short counseling session } \\
\text { (see below), scheduling } \\
\text { follow-up call }\end{array}$ & $\begin{array}{l}\text { Greeting, query regarding } \\
\text { goal attainment, short } \\
\text { counseling session (see } \\
\text { below), goal setting, } \\
\text { scheduling follow-up call }\end{array}$ & $\begin{array}{l}\text { Greeting, query regarding } \\
\text { persistence of maintenance, } \\
\text { short counseling session } \\
\text { (see below), scheduling } \\
\text { follow-up call }\end{array}$ \\
\hline $\begin{array}{l}\text { Typical call } \\
\text { frequency* }\end{array}$ & NA & Monthly & Weekly & Monthly \\
\hline $\begin{array}{l}\text { Topics covered } \\
\text { in the short } \\
\text { (5- to 10-min) } \\
\text { counseling } \\
\text { session }\end{array}$ & $\begin{array}{l}\text { Mailed information regard- } \\
\text { ing the risks of sedentary } \\
\text { lifestyle and the benefits of } \\
\text { exercise }\end{array}$ & $\begin{array}{l}\text { Selected information on } \\
\text { the risks and benefits of } \\
\text { exercise }\end{array}$ & $\begin{array}{l}\text { Assessing aerobic fitness, } \\
\text { barriers, nutrition, self- } \\
\text { management, stress, social } \\
\text { support, enjoying exercise, } \\
\text { emotional benefits }\end{array}$ & $\begin{array}{l}\text { Relapse prevention, handling } \\
\text { of relapse, encouragement }\end{array}$ \\
\hline
\end{tabular}

period. These clinicians generated slightly more than 3,000 referrals (based on self-report of used prescription pads). The number of referrals produced per practice ranged from a low of 10 to a high of 900 , with one half of the practices referring 100 or more patients. Interviews with a sample of the physicians who did not refer indicated that their nonparticipation was driven mainly by system factors such as lost prescription pads and failure to remember the resource was available, rather than disinterest or concerns about the program's efficacy. It also appeared that these practices failed to garner a champion for the project, that is, someone in the practice specifically identified to nurture the study. For those physicians who did refer, poststudy interviews indicated a high level of satisfaction with the program. Referring physicians made such statements as "What a great resource!" and "Can I keep referring to the program once the study is over?" Although studies have documented the effectiveness of telephonic interventions for both smoking cessation and exercise promotion, ${ }^{1,2}$ targeting small, rural practices was unique to this study. Given that rural practices are, by definition, more geographically isolated, finding ways to link them effectively with external resources such as this program could help bridge the access gap. ${ }^{3}$

A second lesson learned was that although this telephonic counseling program appeared to be valued by those enrolled, a single physician referral was clearly not enough to motivate most patients to initiate behavior change. Of the approximately 3,000 patients who were reportedly referred to BeHIP, only 293 made the initial call into the program. This ratio of calls ( 10\%) was disappointing to the research team, as previous experience, reported by BeHIP staff, was that it should be closer to $30 \%$. This reduced ratio could be explained by a geographic effect (eg, physicians thinking "that counseling center is quite far off'), a decrease in initial staging by the referring physician (ie, referral of more patients in the precontemplation stage than in later stages of readiness), overreporting of the number of referral prescriptions handed out (which would actually increase the true ratio), or myriad other physician- or patient-related factors. Research specifically designed to explore the decision process in this population would be needed to clarify this phenomenon further.

Of the 293 inquiries to the program, 119 patients enrolled after hearing details of the study and counseling service. Seventy-one patients enrolled in the exercise program, and 48 enrolled in the smoking cessation program. All of these enrollees have continued to participate in scheduled telephonic counseling, with 3 achieving maintenance (defined as smoking cessation for 3 months or performance of 1,000 kcal of exercise per week for 3 months) at the time these data were reported. Data from this study and previous program experience suggest that the average number of telephonic interactions needed to guide a patient to maintenance is 17 . This number represents significantly more contact than most studies investigate. ${ }^{4,5}$ Such persistent participation by the enrollees in this study suggests a relatively high perceived value for the program. More formal satisfaction and efficacy data will be collected when all participants either reach maintenance or opt to end participation in the program. A costeffectiveness analysis is also planned pending completion of the program by all of the participants. 


\section{CONCLUSIONS}

Linking a telephonic counseling program to rural primary care practices to assist patients in behavior change was well accepted and welcomed by clinicians. Once enrolled, patients seemed to value the program, but additional strategies beyond a 1 -time physician referral are needed to increase patient participation.

To read or post commentaries in response to this article, see it online at http://www.annfammed.org/cgi/content/full/3/Suppl_2/S43.

Key words: Sedentary lifestyle; smoking; telephone counseling; community/public health; health promotion/disease prevention; behavior change; rural health services

Submitted December 21, 2004; submitted, revised, February 21, 2005; accepted March 16, 2005.

Funding support: This project was supported by Prescription for Health, a national program of The Robert Wood Johnson Foundation with support from the Agency for Healthcare Research and Quality.

Acknowledgments: We extend special thanks to the practices in the Kentucky Ambulatory Network that hosted this project: Pennington Family Medicine, Richmond, Ky; Dartt and Hurt, PSC, Danville, Ky; Inez Medical
Clinic, Inez, Ky; Knox Family Medicine, Barbourville, Ky; Primary Care Associates, Glasgow, Ky; Carter County Clinic, Olive Hill, Ky; Dix River Family Medicine, Stanford, Ky; North Gerrard Family Medicine, Lancaster, Ky; Richard Miles, MD, Russell Springs, Ky; James Ferrell, MD, Paris, Ky; Kent Davis, MD, Paris, Ky; William Pratt, MD, London, Ky; Tammy Brown, MD, Albany, Ky; and James Roach, MD, Midway, Ky.

\section{References}

1. Rabius V, McAlister AL, Geiger A, Huang P, Todd R. Telephone counseling increases cessation rates among young adult smokers. Health Psychol. 2004;23:539-541.

2. Pinto BM, Friedman R, Marcus BH, Kelley H, Tennstedt S, Gillman MW. Effects of a computer-based, telephone-counseling system on physical activity. Am J Prev Med. 2002;23:113-120.

3. Ramsbottom-Lucier M, Emmett K, Rich EC, Wilson JF. Hills, ridges, mountains, and roads: geographical factors and access to care in rural Kentucky. J Rural Health. 1996;12:386-394.

4. Zhu SH, Stretch V, Balabanis M, Rosbrook B, Sadler G, Pierce JP. Telephone counseling for smoking cessation: effects of single-session and multiple-session interventions. J Consult Clin Psychol. 1996;64:202-211.

5. Smith PM, Cameron R, McDonald PW, Kawash B, Madill C, Brown KS. Telephone counseling for population-based smoking cessation. Am J Health Behav. 2004;28:231-241.

\section{Establishing a Family-Based Intervention for Overweight Children in Pediatric Practice}

Ellen R. Wald, $M D_{i}{ }^{1}$ Linda Ewing, $P b D, R N_{i}{ }^{2}$ Patricia Cluss, $P b D_{i}{ }^{2}$ Sheri Goldstrobm, $P b D_{i}{ }^{2}$ Lynne Cipriani, $R N_{i}{ }^{1}$ Katbleen Colborn, $B S^{1}$

${ }^{1}$ Children's Hospital of Pittsburgh, University of Pittsburgh School of Medicine, Pittsburgh, Pa

${ }^{2}$ Western Psychiatric Institute and Clinic, University of Pittsburgh School of Medicine, Pittsburgh, Pa

Ann Fam Med 2005;3(Suppl 2):S45-S47. DOI: 10.1370/afm.366.

Conflicts of interest: none reported

CORRESPONDING AUTHOR

Ellen R. Wald, MD, University of Pittsburgh School of Medicine, Children's Hospital of Pittsburgh, 3705 Fifth Ave, Pittsburgh, PA 15232, ellen.wald@chp.edu

\section{PURPOSE}

W e performed a pilot study in 2 pediatric practices to (1) increase the identification of overweight children by the primary care clinician and encourage their referral to an "in-office" family-based intervention, and (2) test the feasibility of an intensive family-based intervention using behavior modification to alter nutrition and physical activity in children who are overweight.

\section{METHODS}

The intervention was conducted at 2 community pediatric practices in western Pennsylvania. One rural practice, approximately 40 miles from Pittsburgh, serves a predominantly white population with low to middle income. The second practice serves a racially and economically diverse urban population in the city of Pittsburgh. Each practice has 10 physicians and 1 nurse-practitioner.

During a 90-minute interactive session, physicians were trained in the use of brief motivational strategies to assist parents in taking steps toward healthier behavior relating to nutrition and physical activity. The identification of overweight children was facilitated by introduction of routine systematic measurement and recording of body mass index (BMI), which was plotted according to sex and age on a color-coded BMI chart, resulting in visual confirmation of the degree of overweight. Physi- 